\title{
The Euro And The European Debt Crisis
}

\author{
Douglas Castleberry, Sam Houston State University, USA \\ Balasundram Maniam, Sam Houston State University, USA \\ Geetha Subramaniam, Universiti Teknologi MARA, Malaysia
}

\begin{abstract}
This paper studies the history of the Euro leading up to its inception, what happened after the Euro was introduced into circulation and implications for its future. The Euro was set up to accommodate a unified currency while preserving sovereignty among nations who, less than a century ago, were mortal enemies. Preserving sovereignty weakened the ability to respond to crisis by design, and it wasn't long before the limits of the European Monetary Union were tested after a series of financial crisis threatened the very existence of the Euro. The Euro held together, yet the inability of the European Central Bank to assist member nations control subsequent debt following the financial crisis may wound the ability of the Euro to replace the dollar as the dominant world currency or even prove fatal. Greece is on the verge of collapse, and is so entangled with other Euro nations; a systemic "domino effect" will occur should any of the troubled member Eurozone nations collapse uncontrollably. Three options remain for the European Monetary Union, banding together and preserving the currency, grossly indebted countries exiting to preserve the health of countries which are more fiscally responsible, or the Euro may land inconsequentially between success and failure, never challenging the power of the dollar as the dominant world currency.
\end{abstract}

Keywords: Euro \& European Debt Crisis

\section{INTRODUCTION}

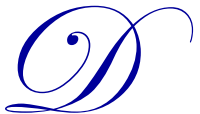

ecisions made by Eurozone nations at the start of the second decade of the twenty-first century will decide whether the Euro becomes a contender on the world stage and challenge the dollar, implode after uncontrolled defaults of Greece, Ireland, Iceland, Portugal and Spain, or end up somewhere inconsequentially between. Debt levels of some Eurozone nations such as Portugal, Ireland, Iceland, Greece and Spain, which comprise the main cause of concern regarding the Euro and Eurozone stability, reached critical levels in 2009 and 2010. Eurozone political leaders find the task of preserving the Euro difficult, since bailing out indebted nations is not perceived well among respective constituencies and negatively affects re-election prospects. Another reason Eurozone member nation decisions are critical during this period is because of the apparent ineffectiveness of the European Central Bank in responding to crisis. The European Central Bank struggles because of the balance between fiscal sovereignty of member Euro nations and common needs.
\end{abstract}

The current weakness of the Euro lies in the need of member Eurozone countries to keep a certain level of sovereignty. After their involvement in WWII just half a century earlier, Eurozone nations feel the need to protect themselves and not trust other nations. Even with a level of trust required to pull the Eurozone together, dissention and prejudices of constituent populations are another road block to the success of the Euro. Actions which could be considered bailouts of nations like Greece, who took on more debt than they could handle to support their lifestyle, are greatly frowned upon by other voting publics in Europe, especially nations which already feel a level of contempt after the war. The critical status of the Euro did not happen in a year or even in a decade; the Euro reached its current critical stage by the action or inaction of member nations over the span of decades.

Plans to develop a single European currency resulting in the current twenty-seven member states of the European Union began twenty years ago. Among reasons Europeans sought a unified currency were: power and leverage in the world market, alleviation of currency exchange burdens when travelling or doing business with other firms in Europe with different currency in the form of bank fees, and the normalization of the price of goods in 
Europe from country to country (Silvia, 2004). When the Euro was initially discussed in the 1990's, it was thought that having a unified currency would encourage specialization among the European nations. Specialization would utilize greater economies of scale and reduced transaction costs (Silvia, 2004). The structure and plan for the Euro was so sound, the only Eurozone state which did not join was Great Britain, but mostly because of public opinion. The British public did not approve of moving to the Euro, so forcing the decision to do so would prove too difficult for politicians. The reluctance to join the Euro by Great Britain, interestingly, had little to do with the soundness of the Euro idea (Walsh, 2007). Considering the Euro was constructed on such a seemingly sound foundation, this paper explores contributing factors for the inability for the Euro to handle the crisis smoothly then formulates conclusions about its future based on its history and current challenges.

\section{THE EURO, FROM DREAM TO INCEPTION}

The Euro began as an idea within the European Union to unify the currency of Europe so European countries may trade more fairly and easily within Europe. A unified currency for all of Europe just made sense and was backed by all countries in Europe with the knowledge the European market is larger than the United States, who currently possess the lion's share of currency trades world-wide. When surveying citizens who were for and against a unified currency, it was found proponents of the unified currency were more psychologically rational than opponents (Gartner, 1997). Even the people of Germany, who understood their economy was superior to other European countries by far with the exception of Great Britain, strongly supported and encouraged the idea of a unified European currency.

Unifying the Euro nations under a single currency takes advantage of economies of scale to compete more aggressively in the world market. External trade in 1996 from the United States totaled \$1.7 trillion, while trade from all of Europe equaled \$1.9 trillion (Bergesten, 1997; Salvatore, 2001; Candelon \& Palm, 2010). Because of the size of the European financial market as a whole, especially in the late 1990's (data from 1996), introduction of a common currency reduces risk involved with external factors such as international market fluctuations.

Since World War II, after the United States surpassed the Pound Sterling as the dominant world currency, the dollar (Bergesten, 1997) has far exceeded its level of world output in world finance (Portes, 2002). In 1996, the United States made up $27 \%$ of world output and $18 \%$ of world trade, while the European Union accounted for $31 \%$ of world output and $20 \%$ of world trade. World finance participation by the United States, however, made up 40$60 \%$ of total activity (Bergesten, 1997). Prior to the introduction of the Euro, the deutsche mark was the only dominant world currency of future European Union member nations, yet dollars made up as much as five times the levels of deutsche marks in the world market in 1996 prior to the introduction of the Euro in 1999 (although Euros did not begin circulation until 2002). Seventy-one percent of the German people were opposed to the introduction of the Euro at the height of the Euro debate in 1998. Although political parties touted the Euro as a grand unifying currency which would be for the greater good and challenge all other currencies was not accepted by the populace, who did not trust the lawmakers and felt the cost of accepting the Euro would outweigh the cost of converting to the Euro (Zimmermann, 2001). Because of their experiences with unstable currency in the twentieth century, Germans were reluctant to change currencies since their own currency performed so well; the deutsche mark was the only internationally traded European currency among nations who joined the European Monetary Union (Bergesten, 1997). To pass the measure to join the Eurozone, politicians maneuvered around voters to accept the unified currency and went against the will of the majority of Germans. Ironically for the German people, the gradual weakening of the Euro after its inception helped the people of Germany. The people who benefit from a strong, tightly held currency are international investors, financial institutions and investors. A weaker and loosely-held currency assists laborers, borrowers and exporters (Frieden, 1998). A weakening currency actually helps the German people, yet Germans were apprehensive about the change to the Euro because of frustration that lawmakers did not allow the public to weigh in on the decision to adopt the Euro. Frustration was expected to quickly subside because of cognitive dissonance theory. The German people did not have a say in which currency to use, so their apprehension was great, yet after the release of the Euro they were expected to become less angry since they feel they have no choices (Isengard, 2007). In the long run, the cognitive dissonance theory was correct, yet in the short run, Germans were defiant and agitated since they felt a measure of freedom and choice was taken from them when the Euro was adopted without public approval. Even though frustrated, the long term benefits to Germans as well as all other Eurozone nations relied on arithmetic, not passion. 
Eurozone governments knew initial conversion to the Euro would be expensive, so the savings in conversions of currency and other inefficiencies had to outweigh the cost of maintaining an inefficient decentralized currency. Vending machines would need new scanners, new bills and coins would require minting, and all stores across Europe would need to re-price their shelves to adjust for the new currency. Often, companies tend to price items at marketable values such as $\$ 9.99$, appealing to customers looking for a bargain. After much debate and negotiation within Eurozone nations, it was decided the cost of introducing a new unified currency justified the benefits and the Euro was founded.

\section{THE BEGINNING OF EURO}

After the Euro was introduced in January, 1999, it declined in value relative to the dollar. Schnatz (2004) published two reasons for the initial decline of the Euro. The first reason is an exceptional increase in value of the dollar at that time. Increased demand of the dollar in world markets because of American productivity (Schnatz, 2004) at the time inflated the dollar artificially. Another external factor was the rise in oil prices at during the period of introduction. Strong evidence suggests rising oil prices were a significant cause of the Euro's value relative to the dollar weakening (Lewis, 2007). The second reason for the Euro decline against the dollar is instability in Eurozone labor markets as well as overall perception of European countries using accounting methods to falsely show healthy economies to enter the single currency (Arestis, Biefang-Frisancho Mariscal, Brown, \& Sawyer, 2002). Evidence is shown in this article to show growth in the United States during the period of introduction of the Euro, although real, was not a significant cause of the decline in value. A rise in overall deficit spending by member countries and a normalization of inflation rates in the region caused the initial decline in value.

Deficit spending is not only a cause for the initial decline in the value of the Euro, but also a major cause of the European Debt Crisis. The European debt crisis began with poor private investments, when governments secured bad private debt. The private debt crisis soon moved to government debt crisis. Rogoff (2002) indicated that "Essentially, there is still a risk that the financial crisis is simply hibernating as it slowly morphs into a government debt crisis" (Begg, 2002). The same article identifies three different reasons a debt crisis would naturally follow the financial crisis. The first reason is direct payments as a safety net for private financial debts. As European governments insured private losses in the financial system and acted as a safety net, public debt was racking up. The idea of allowing private profit on public risk became the status quo after governments around the world began to bail out and guarantee financial lenders and insurers to prevent panic and runs on banks to withdraw cash. The second reason a public debt crisis was expected is public guarantees of commercial bank loans. Because these guarantees are not direct payments but liabilities held, debt liability will skyrocket public debt in the event of a downturn. Holding the liability also increases the risk premium for the country in case of private default. The third reason the debt crisis was anticipated is due to economic stabilization. High unemployment after the financial crisis not only lowers the amount of tax government receives but causes government to pay out more in benefits to impoverished and unemployed citizens. Some nations, such as Greece, were so debt-ridden they were not allowed to join the Eurozone when it began in January 1999 because they did not meet the four Maastricht indicators (Salvatore, 2001).

It seems now Greece should not have been allowed to join the Eurozone after inception, since Greek credit default swaps and huge entitlements eventually became so large they caused interest on debt to be larger than their capacity to pay and the European Central Bank was unable to quickly respond with measurable action (Mitchell, 2011). Ways to prevent crisis such as deflating the value of the Drachma or reducing interest rates existed, but involvement in the Euro prevented an agile response because the Euro currency was built with a lack of central power to make decisions. Greece has been under much scrutiny from the United States because of their instability after Standard and Poor's reduced Greece's credit rating on April 22, 2010 then on June 14, 2010 reduced Greece's credit rating to the lowest status possible and caused interest rates to skyrocket, since Greece is a major importer of goods from the United States. Rating Greece in the almost junk bond category also hurt the country's ability to issue bonds which have a reasonable return. Uprisings in 2010 after attempts by Papandreou to enforce austerity measures to ensure Greece can pay down its debt are worrisome for the government of Greece, since it is a sign the people of Greece are not prepared to suffer the pain of solving their debt crisis. Even though Papandreou did win funding for a five year austerity plan, it cost him so much political capital that in a later agreement he had to step down. The most recent bailout of Greece is not the only bailout. Papandreou is responsible for reducing pensions 
20 percent, receiving short-term loans from the EU so not to default on immediate debt obligations as well as a bailout in exchange for concrete debt reduction. Greece was not the only nation in the Eurozone to have debt issues. Iceland is another nation whose debt built up over the years and is part of the reason the Euro is in crisis.

Iceland had one of, and arguably the most significant, debt crisis and banking system emergencies due to a similar housing bubble problem experienced by the United States. Creative real estate loans countering inflation of Icelandic currency, which ran anywhere from ten to fifty percent, were being issued to borrowers. The method of loaning funds ended up being a perfect storm of disaster for Iceland's banks and her public. When the real estate bubble popped, everyone now possessed a sub-prime mortgage and could not move if they wanted or needed to. Banks invested in the rent house market to mitigate their loss, but even the renting market was impossible since Icelanders could not afford to rent. Icelanders knew the risks involved with accepting their loans, yet times were good and society as a whole accepted the practice as commonplace. Banking systems in Iceland froze and demonstrators filled the streets when they were unable to draw their funds from banks after Icelanders made a run on banks in the country. Iceland quickly nationalized banks in the country to stop a chain reaction like what happened (on a more extreme scale) in the United States during the great depression.

Ireland's issues were related to government-backed real estate, which encountered systemic default around the same time the United States suffered the same systemic failure due to sub-prime mortgage lending. Other countries share Iceland's housing collapse in the Eurozone, most notably Spain.

Although Spain also suffered the collapse of a housing bubble, Spain's largest debt issue was the stagnation of their economy by slowing growth. Austerity measures caused unemployment of workers in their twenties to soar to around $50 \%$. When budget deficits ended up doubling from their projections in 2010, Spain's credit was downgraded from triple A to double A plus which caused interest rates to rise. When issuing bonds, not only were interest rates high because of the low level of liquidity but an additional premium for uncertainty (for Spain as well as Italy) existed (Codongo, 2003). Rating agencies were concerned Spain's austerity measures would cause growth to slow and unemployment to rise, and they proved correct. Young people in their twenties crowded town squares to protest the staggering unemployment rates of young workers in the country.

The housing market collapse in Iceland, Ireland and Spain coupled with the debt crises caused the five countries known as PIIGS, Portugal, Ireland, Italy and Greece to carry unmanageable levels of private and public debt, requiring action on the behalf of all countries since the establishment of a central bank with the ability to fix the crisis was not established at the beginning. Without a central bank inflating or deflating the Euro (although it does possess the authority to print money) like the Federal Reserve in the United States, European countries had to unanimously decide whether to bail out countries with high debt. The problem with bailing out countries like Greece is entitlements for Greek citizens are way higher than entitlements and surrounding Eurozone countries. Bailing-out countries with more entitlements is a hard pill to swallow for European countries. In the most recent case Greece had to be shown favoritism, but Greece has more entitlements than other countries so one country in particular wanted to require that Greece put up collateral to be shown that favoritism. Natural steps that need to be taken to inflate the currency across Eurozone countries and enact fiscal measures that would prevent astronomical debt which would hurt the Euro. Another fix sought was to strengthen the European Central Bank and allow it to be able to make decisions quickly without unanimous vote from member countries of the Euro. The inability of the European Central Bank to effectively be the lender of last resort means the Euro becomes unable to respond to crisis of member countries. Allowing member countries to leave the Euro could begin a quick withdrawal of member countries in trouble. Member nations leaving the Eurozone is a great example of how the Eurozone differs from the structure of the United States and the relative instability compared to the dollar. The United States, although very stable politically compared to the Eurozone, does make mistakes in monetary policy which affect the Euro.

The United States could have had a direct affect on the European debt crisis. The clearest example of American influence is the case of Iceland and the housing crisis discussed above. Iceland banks, after seeing the American model of housing financing, chose to mirror the model and suffer the same fate. The main reason the United States is in a better position than European nations who modeled financial institutions is because the scale of debt in the United States is significantly smaller in relation to their GDP than that of Europe. To put it simply, America could afford to bail out their banks and Europe could not. One side effect of American influence in 
European banks which led to the most recent crisis is a loss of influence and respect foreign banks used to hold for the United States. When the United States bailed out banks in the initial round of the housing crisis and banks considered too big to fail, it is reasonable to assume leaders in Europe used the decision made by the United States as a strong consideration for the response to their own debt crisis, and in the case of Iceland, almost the exact issue America found themselves in regarding the housing crisis and credit default swaps, yet on a much larger scale (or at least a more chaotic scale).

\section{CURRENT SITUATION OF THE EURO}

Europe, although having several unlikely successes including the unanimous decision to "bail out" Greece, is in trouble financially. No effective controls are in place to prevent Greece from continuing to consume beyond their means. Italy, Portugal, Iceland and Ireland are tied to the collapse of Greece. Should Greece not change its ways, Greece will have to exit the European Union to preserve PIIGS from collapse since all the countries are so closely entangled financially. The internal value of the Euro within the Eurozone countries depends on how stable the prices are. Prior to the Euro, prices saw little volatility in inflation and prices which supported a strong Euro at first. Initial re-pricing of all goods to convert to the Euro caused slight instability at first but can be expected to level off over the long run (van Aarle, Hlouskova, \& Michael, 2000).

Europe is not as healthy as a whole now as it was before the Euro was accepted, although in the short term, the Euro did seem to gain in health until the later debt crisis (Candelon \& Palm, 2010). Backslides in participating European countries began as soon as the Euro was brought into existence. Reconstructing prior currencies participating countries had, took participating European countries to the economic level they saw in 1985 (Clairmont, 2000). This year's debt rating reduction is a sure sign Greece is in huge trouble. The projected Debt/GDP ratio at the end of 2011 (IMF estimate) equals 365 billion Euro in debt and 136 billion Euro in GDP, or $165 \%$. To make Greece sustainable without defaulting or being bailed out, Greece would need to cut its debt by $64 \%$, down to 227 billion Euro to reach the 2001 debt level of $103 \%$ of GDP (Albano, 2011). To comply with European Monetary Union pacts, Greece would need to reduce debt to 60\% of total GDP, or 233 billion Euro. Members of the European Central bank, who act as a lender of last resort for Eurozone countries, does not believe there is a viable solution in place to restore confidence in the Euro to be able to reduce the cost of debt. Germany does not want the European Central Bank to be the lender of last resort similar to the way the United States and Great Britain are structured with their independent central banks. One solution Germany is currently resisting is the issuance of common bonds to restore some level of confidence by issuing common debt and dragging on the people of Germany and other producing States. The European debt crisis is becoming more and more systemic, and is in a position to affect more than just Europe. Jean Claude Trichet, ECB, is currently encouraging swift action by monetary authorities. Greece is fully expected to default on its debt. Swift action in the form of debt compliance and rescue funds are encouraged by Trichet as the means to quickly prevent an uncontrolled collapse of the Euro. Swift action is the only way to solve the problem. If Greece defaults and causes other countries to default as well, the Euro would collapse and become inefficient since it would drag down strong economies involved with the Euro. Another side-effect is the Euro, which was supposed to take advantage of the huge economy when all of Europe is united, would no longer be able to possess a higher level of GDP than the United States and the dollar would continue to hold its position as the currency of choice when it comes to international trade and a secure currency which to invest in. The Euro was supposed to replace the dollar as the currency of choice and provide a strong alternative to the dollar countries could invest in. Should half the countries utilizing the Euro default, stronger countries such as Germany would have no choice but to remove themselves from the plummeting Euro by dissolving the partnership between themselves and defaulting countries or to return to their original currencies. All countries will lose should the Euro crash uncontrollably. Recent debt issues with the Euros have revealed political differences in Europe. Gerhard Schroeder encourages all involved with the Euro to prop up countries in trouble and avoid nationalism of member country's currencies and save the Euro. Saving the Euro will take bold reform and enormous leaps toward centralized decision-making. More integration in Eurozone countries would help save the Euro but would reduce the level of sovereignty of member nations in the Eurozone. Half measures will hurt everyone, so member nations must now weigh the cost of sovereignty. If the Eurozone breaks down, not only member nations will suffer, but countries who invested or are tied to the Eurozone will be affected. Nobody has the knowledge to know if the Euro will work. Leadership dynamics across Europe control the future of the Euro. The 
European Central Bank is attempting to change the culture of some of the oldest governments and civilizations on earth, and this attempt is totally unpredictable.

What is building in Europe is anger. Citizens are apprehensive about the future of their currency. Greeks are concerned programs they paid into with certain expectations will be stripped due to outside controls, yet Greece cannot control the valuation of the Euro, so is stuck in a debt crisis with no way to adjust their currency to assist themselves sin the most beneficial way. Anger is building in prosperous countries, since citizens feel they should not have to pay out of their pocket for the entitlements of countries that lived beyond their means for too long. With all the anger building in Europe, the probability of an uncontrollable collapse increases. Lawmakers in the respective countries have a terrible time rallying long term support for programs which would be better for Europe as a whole, since they must at all times be concerned about elections in the short term and giving the appearance of protecting the citizenry of their country and not favoring the prosperity or over-enrichment of citizens in another country.

Citizens have a huge impact on lawmakers now, since the anger is building. Riots in Iceland and Greece was a strong wakeup call for lawmakers across the Eurozone which are faced with two conflicting problems: 1) If an uncontrolled devaluation of the Euro occurs with the domino effect default should countries beginning with Greece default, riots would happen in their own streets and lawmakers would be viewed as unable to deal with monetary issues and be voted out with a shameful legacy of failure. 2) If lawmakers make selfless decisions regarding long term viability of the Euro, then citizens would still vote the leader out of office since the leader is favoring the prosperity or undue enrichment of other states instead of the prosperity and enrichment of their own citizenry. These two conflicting problems, coupled with little central control of the European Central Bank to be able to use joint funds for the protection of the group as a whole in favor of maximizing sovereignty, lead to ineffectiveness and frustration amongst leaders in the Eurozone. The ultimate commodity and final repository of value in any nation is its currency, and currency is valued by confidence both internally within a state as well as externally internationally. The Euro's attempted usurpation of the dollar and challenge to American imperialism does not seem to be working currently (Clairmont, 2000). Spats between European political leaders have been a detriment to the success and agility of the currency. Without central control, the Euro suffers because of political posturing and decentralized disagreements in how Euro policy should run. The Euro was arguably doomed for chaos from its inception. Three mechanisms normally required for a sustainable currency, which do not exist in the Eurozone are: homogeneity of economies, flexibility which would allow for regional adjustments, mobility of factors which prevent asymmetric shocks and fiscal transfers that can be used to achieve regional stabilization (Begg, 2002). Other reasons the Euro struggles because of design are lack of a unified and empowered central bank, politicians' goals are more short-term than a bureaucrat working in the central bank, lack of unified purpose and a natural level of distrust between states not conducive to a unified currency.

\section{LESSONS LEARNED FROM THE EUROPEAN DEBT CRISIS}

The first lesson which can be learned from the European Debt Crisis is the importance of enacting austerity measures as soon as possible. The worrisome element of the collapse in Ireland and subsequent bailout by both the International Monetary Fund and the European Union is the fact that the level of debt prior to the collapse is comparable to the amount of debt in the United States, which should serve as cause for concern to other world nations including the United States. Ireland should serve as a wake-up call to the United States to begin austerity measures soon.

The second lesson which can be learned from the European debt crisis is to not allow debt to skyrocket by allowing deficit budgets year after year. Greece is a great example of an already overburdened economy getting a slight nudge and toppling over the edge in crisis. Greece's entitlements and social-leaning government created a relatively lavish lifestyle for her citizenry, yet the same entitlements caused the government of Greece to be locked in a state of provisioning her citizens with excessive entitlements. When Greece made moves toward removing some of the long-held entitlements from citizens, much resistance and opposition by citizens occurred. Massive protests in Greece began on May 5, 2010. The riots were so socialistic in nature the movement calls itself the "Indigent Citizens Movement." Although indigence is close to foul language in the United States, socialist rhetoric is becoming quite commonplace and mainstream in the "Occupy" movement in the United States. The Occupy 
Movement demands things like jobs for everyone and free health care, which sounds quite similar to the demands in Greece.

A third lesson which can be learned from the European Debt Crisis is to ensure conflicts of interest do not occur in lending. Lenders should be held accountable for the loans they issue to ensure they are making decisions which are beneficial to the long term health of securities bought and sold. Iceland's home lending problem occurred not because everyone involved did not understand the risk they were taking. Icelanders knew the risk of taking a loan at a low interest rate which could skyrocket over time. Icelanders knew it was commonplace to take on the excess risk of the loans since everyone else was doing the same thing. Since most of Iceland's population took on the same risk, the fallout systemically caused most of the population to hold subprime mortgage loans.

\section{POSSIBLE OUTCOMES OF THE EURO}

The European Union cannot afford for the Euro to collapse, yet collapse seems to be the most logical outcome. Euro zone countries consist of consumers such as Portugal, Ireland, Italy Greece and Spain, as well as producer countries such as Germany, the Netherlands, Austria and France who spend more than their income and ran deficits. The PIIGS are in fear of an uncontrolled exit from the Euro, since it seems unable to adjust to crisis. Greece is on the verge of a quite ungraceful exit from the Eurozone. If peripheral countries begin to exit the Euro, the Euro will become weaker. Core members of the Euro can barely stand to bail out nations with high debt and high entitlements, but the shift of income may be necessary to save the currency in the short term.

One possible outcome for core countries is to coach countries with high debt to restructure their methods of financing and insist they discontinue the trend of spending more than is made by treaty terms. Peripheral countries will not like the solution of spending less than is made because this will mean short-term hardship for the citizens of the countries, especially since the initial goal would be to pay back the debt and run at a surplus. Restructuring debt in troubled countries does not seem palatable both for the countries which would bail the smaller countries out and for the peripheral countries which would have to excuse loans and assist other countries with problems they did not help create. Should Italy default on its loans it could lose its ability to obtain loans and, like in the case of Greece, would have to forcibly restructure since it could not access credit.

Another option for the Euro is to fully empower the European Central Bank and bind member nations' fiscally, giving up a large measure of sovereignty but preventing an uncontrolled collapse of the Euro zone. The European Central Bank does not want to be the bank of last resort because it does not want to take the risk. If the European Central Bank is not empowered, Italy could have to leave the Eurozone (or be forced to leave) and Spain is just as bad as Italy. A series of defaults could systematically occur which would cause troubled nations to either voluntarily from the Eurozone or be forced to leave. Some credit agencies are considering downgrading France's credit rating, which could uncontrollably increase debt rates since interest rates would then be higher. The breakup of the Eurozone could be chaotic if the plug is pulled all the sudden. To make the breakup of the Euro smoother, the European Central Bank would have to contribute to exiting nations to prevent financial crisis in those nations. The size of the problem in Greece in Spain is so large-scale the countries are too large to bail out. There is a real danger of a financial meltdown in Europe if the Euro falls uncontrollably which could be possible by an uncontrolled default in Greece.

With so much debt in relation to the total size of the European economy, Europe could be stuck in a debt trap since the burden to hold so much debt Europeans would be unable to pay back. One possible solution is to separate troubled countries from the Eurozone and allow them to fail as a group. It seems although Greece was bailed out, debt continues to rise. Allowing Greece to go bankrupt could cause other PIIGS to collapse as well since the governments are so tightly interconnected. If Greece goes bankrupt now, the fall could be less traumatic than if Greece is bailed out and allowed to continue borrowing more money, then defaults down the road with even more debt. Many scenarios are possible in the near future. In this scenario, Greece would collapse, followed by Spain and Italy. The reason this scenario is unlikely is because of the amount of debt the Eurozone holds in aforementioned nations. If Greece, Spain and Italy are removed from the Eurozone, their debt is still in Euros, so all money invested to-date by the European Central Bank would surely be defaulted on. 


\section{IMPLICATIONS FOR THE FUTURE OF THE EURO ZONE}

No situation, except the total economic collapse of the United States, would result in the Euro usurping the dollar as a world currency. Two assumptions may be made about the future of European debt and the Euro: 1) The Eurozone cannot afford for the Euro to collapse and can be expected to aid countries in trouble instead of divesting them. 2) The dollar is currently more reliable than the Euro and will continue to be for the foreseeable future (Cohen, 2007). Uncertainty about the effectiveness and structure of the European Monetary Union will continue to haunt the Euro as it tries to earn respect as the leading world currency. Tight monetary control and the structural inability to prevent deflation in specific Eurozone areas cause internal tension amongst member states (Silvia, 2004). Transaction costs, which were supposed to decline after unifying the currencies actually increased and prices rose to adapt for increases in inventory risks due to transparency of spot trading (Carsten \& Phillip, 2002). The current structure and constituency of the Euro will change in times ahead by either imploding with the uncontrolled collapse of debt-ridden countries or dragging down the wealth of performing countries bailing out their indebted allies.

\section{AUTHOR INFORMATION}

Douglas Castleberry holds a MBA from Sam Houston State University.

Balasundram Maniam is a Regents Professor of Finance at Sam Houston State University. He has published numerous referred journals articles. He is currently serving as the editor, associate editor and editorial board member of several journals. E-mail: maniam@shsu.edu (Corresponding author)

Geetha Subramaniam is a senior lecturer at Universiti Technologi Mara, Malaysia. She has published numerous referred journals articles. E-mail: geethamaniam@gmail.com

\section{REFERENCES}

1. Albano, V. (2011). Reuters. Retrieved 2011 from http://www.reuters.com/video/2011/10/17/ greece-debtto-need-64-haircut-to-achiev?videoid=223376266

2. Antoniades, A. (2007). Examining facets of the hegemonic: The globalization discourse in Greece and Ireland. Review of International Political Economy, 14(2), 306-332.

3. Arestis, P. A. (2005). Financial globalization: The need for a single currency and a global central bank. Journal of Post Keynesian Economics, 27(3), 507-531.

4. Begg, L. (2002). The Euro: A success against the odds? Eastern Economic Journal, 28(1), 25-44.

5. Bergesten, C. F. (1997). The Dollar and the Euro. Foreign Affairs, 76(4), 83-95.

6. Bibow, J. (2002). The markets versus the ECB, and the Euro's plunge. Eastern Economic Journal, 28(1), 45-57.

7. Candelon, B., \& Palm, F. (2010). Banking and debt crises in Europe: The dangerous liaisons? CESIFO Working Paper No. 3001, 1-25.

8. Cannon, E., \& Giam Pietro, C. (2006). Euro-illusion: A natural experiment. Journal of Money, Credit, and Banking, 1391-1403.

9. Clairmont, F. F. (2000). The Euro crash. Economic and Political Weekly, 35(41), 3,644-3,646.

10. Codongo, L. A. (2003). Yield spreads on EMU government bonds. Economic Policy, 503-532.

11. Cohen, B. J. (2007). Enlargement and the international role of the Euro. Review of International Political Economy, 14, 5.

12. Cyr, A. I. (2003). The Euro: Faith, hope and parity. International Affairs (Royal Institute of Internaltional Affairs 1944, 79(5), 979-992.

13. Deroose, S. A. (2007). The legitimation of EMU: Lessons for the early years of the Euro. Review of International Political Economy, 14(5), 800-819.

14. Dominguez, K. M. (2006). The European Central Bank, The Euro, and global financial markets. The Journal of Economic Perspectives, 20(4), 67-88.

15. Dziuda, W. A. (2009). The Euro changeover and its effects on price transparency and inflation. Journal of Money, Credit and Banking, 41(1), 101-129. 
16. Ehrmann, M. A. (2005). Equal size, equal role? Interest rates interdependance between the Euro area and the United States. The Economic Journal, 115(506), 928-948.

17. Els, P. V. (2003). New macroeconomic evidence on monetary policy transmission in the Euro area. Journal of the European Economic Association, 1(2/3), 720-730.

18. Fabbrini, S. (2000). Political change without institutional transformation: What can we learn from the Italian crisis of the 1990s? International Political Science Review/Revue internationale de science politique, 21(2), 173-196.

19. Faruqee, H. (2006). Exchange rate pass-through in the Euro area. IMF Staff Papers, 53(1), 63-88.

20. Gartner, M. (1997). Who wants the Euro -- and why? Economic explanations of public attitudes towards a single European currency. Public Choice, 93(3/4), 487-510.

21. Henning, C. R. (2007). Democratic accountability and the exchange-rate policy of the Euro area. Review of International Political Economy, 14(5), 746-773.

22. Hugon, J. H. (1971). Past and future of the Euro-money market. Financial Analyst Journal, 27(5), 21-24.

23. Isengard, B. A. (2007). Attitudes toward the Euro: An emperical study based on the German socioeconomic panel (SOEP). Social Indicators Research, 82(1), 35-56.

24. Kokoszczynski, R. (2001). Poland before the Euro. Journal of Public Policy, 22(2), 199-215.

25. Lane, P. R. (2006). The real effects of European Monetary Union. The Journal of Economic Perspectives, 20(4), 47-66.

26. Lewis, V. J. (2007). Productivity and the Euro-Dollar real exchange rate. Review of World Economics/Weltwirtschaftliches Archiv, 143(2), 324-348.

27. Portes, R. A. (1998). The emergence of the Euro as an international currency. Economic Policy, 13(26), 305-343.

28. Portes, R. (2002). How has the Euro changed the foreign exchange market? Economic Policy, $149-191$.

29. Salvatore, D. (2001). The Euro: Expectations and performance. Eastern Economic Journal, 28(1), $121-136$.

30. Schnatz, B. A. (2004). Productivity and the Euro-Dollar exchange rate. Review of World Economics/Weltwirtschaftliches Archiv, 140(1), 1-30.

31. Silvia, S. J. (2004). Is the Euro working? The Euro and European labour markets. Journal of Public Policy, 24(2), 147-168.

32. Walsh, J. I. (1976). How and why Britain might join the single currency: The role of policy failure. Review of International Political Economy, 14(5), 868-892.

33. Williams, M. (1976). Money creation in the Euro-Currency market. Weltwirtschaftliches Archiv, 112(2), 201-230.

34. Zimmermann, K. A. (2001). The Euro and political credibility in Germany. Challenge, 44(5), 102-120. 


\section{NOTES}

